\title{
The Role Of Women Labourer In Agricultural Development Of Karachi, Sindh
}

\author{
Rukhsana \\ Women's Studies \\ University of Karachi \\ Nasreen Aslam Shah \\ Social Work \& Women's Studies \\ University of Karachi
}

\begin{abstract}
Agriculture plays a very important role in providing food and raw material for industries that is why it is acknowledged as the back bone of agrarian societies. Globally, women contributed remarkably in the agriculture sector. Pakistani women are also playing an important role in the agricultural and economic development of the country. Although Karachi is famous around the world as a large metropolis and industrial sector, but the surrounding sub-rural areas also play a big role in the agriculture sector and women are also equal contributor of this sector. The objectives of this study to highlighted the role of women labourer in agricultural development of Karachi. The researcher used purposive sampling method to collect data through interview schedule from 200 women agricultural labourer of sub-urban Karachi. The findings of the study highlights that these women work equal as men but earn less. They work eight to nine hours daily in the farm but get only100-120 rupees per day. They do not spend their income as their own choice. In addition, they work to increase their daily livelihood along farm work. The study concludes that introduction of new technical courses and training for agriculture and market requirements would help women farmers to improve their income and financial status.
\end{abstract}

Keywords: Agriculture, Women Farm Labourer, Economic Development.

$$
\begin{aligned}
& \text { تلخيص }
\end{aligned}
$$

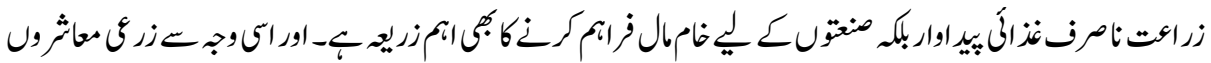

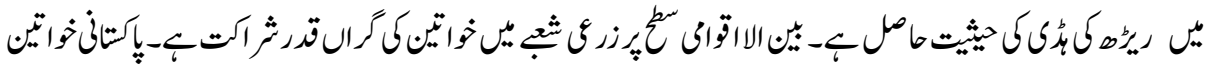

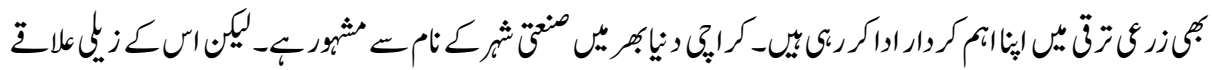

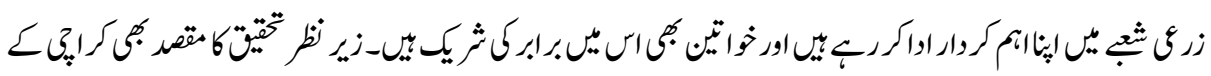

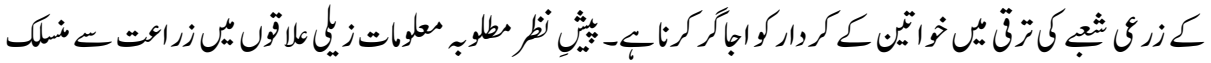

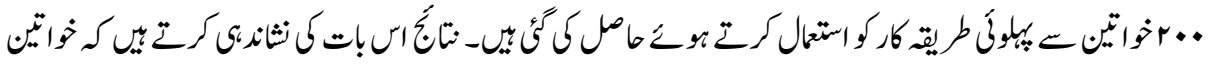

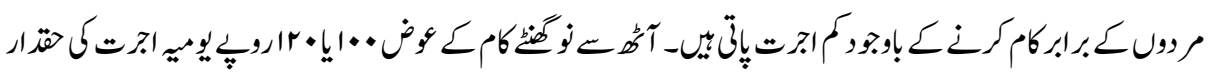




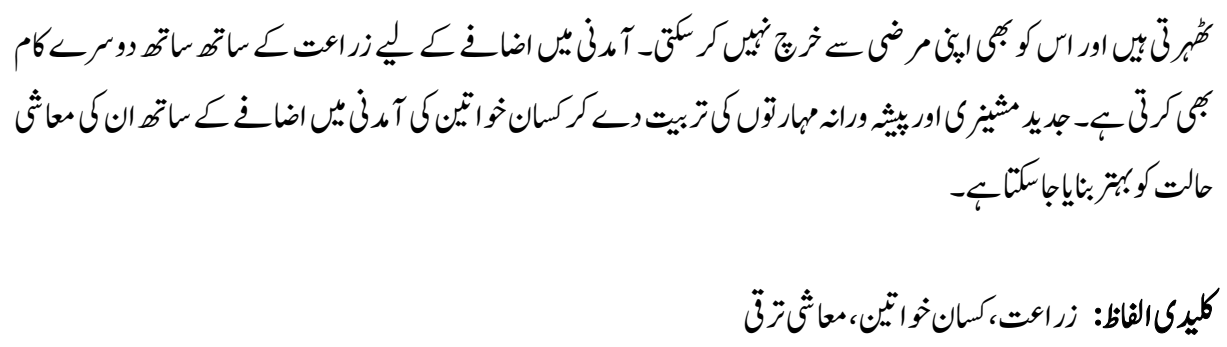

\section{Introduction}

Agriculture plays a very important role in providing food and raw material for industries that is why it is acknowledged as the back bone of agrarian societies (Wasnik, 2006). Women contributed remarkably in the agriculture sector. According to FAO (2016) report, globally women play an important and central role in agriculture including employment and food production. Worldwide women contribute $43 \%$ of the agricultural labour force, ranging from $20 \%$ in Latin America to almost $50 \%$ in sub-Saharan Africa. Women also play a significant role in agriculture production in Europe and Central Asia, and form a valuable part of the agriculture labour force. The female contribution in agricultural labour force in Central Asia is $41 \%$, Western Europe 32\%, Eastern Europe $29 \%$ and Southern Europe 45\% (FAO, 2016). In China, women constitute about $70 \%$ of the agricultural labour force and perform more than $70 \%$ of farm labour. In India, $75 \%$ of all women workers are in agriculture. Even in comparison with other business segments, women's participation in agriculture is relatively increasing (Lu, J. L., 2011).

According to human development report, agriculture is still an important source of work, with 1.34 billion people worldwide working in or seeking work in agriculture (Human development report, 2015). According to the Asian development bank sub-index score, the highest female participation in the agricultural labour force in the South Asian region is in Nepal, which is mainly an agricultural society and majority of those engaged in agriculture are women working as unpaid family labour (Asian Development Bank, 2015).

Pakistan is basically an agricultural country where $70 \%$ of its population lives in the rural and sub-rural areas and $80 \%$ are involved directly or indirectly in agriculture. In Pakistan $48.65 \%$, the total population consists of women and the majority lives in the rural and sub rural areas. Women have limited opportunities to work in rural areas of Pakistan. Pakistan has an estimated population of 180 million, of which only 12.51 million females have an employment of some sort (Mirza, 2014).

According to Pakistan labour force survey report, all women working inside or outside home, paid or unpaid work, and with no differentiation between rural and urban areas. In 
urban areas women participate in the organized and formal sectors; while in rural areas women are involved both in the organized and unorganized sectors. They predominantly work in agriculture with men, but unfortunately their work is unrecognized and did not consider valuable (Labour Force Survey, 2014-15).

Karachi is the capital of Sindh province and is known as the major industrial city of Pakistan, which contributes $70 \%$ of its income as revenue to the federal government and plays a very important role in country's overall economy. However, it is surrounded by fertile green area where fruits, vegetable, wheat, cotton, millet and betel leaf (paan) is also cultivated. This area known as Malir is famous for its vegetables and fruits which help to fulfil a large percentage of the food requirement of the people of Karachi. Banana and wheat cultivation has stopped due to unavailability of water. Agriculture is depended upon the water from the Malir River and wells in its catchment areas. Unfortunately, due to the lifting of gravel and sand from its river bed has caused a deficiency of water and this has badly affect the agriculture in the area (Nergus, 2005). In Pakistan, most of the farmer's families are poor and the women of these families work together with their male family members and thus increase the overall family income. The situation is the same in Karachi's agricultural areas, where women work along with men and participate in all farming activities.

Unfortunately statistics has never displayed the real contribution of women in the agricultural sector labour force, even though they have been responsible for processing and preparing food, collecting wood for fuel and fetching water, caring of family member and maintaining their home since ancient times. They work more than men the whole day and help in increasing their family income and saving, but this is not shown in national income. Women are involved subsequently in agriculture activities but their role remains invisible and appropriate statistics are not available. In fact, women were not awarded their wages which were received by their male family members (Brownlee, 1976). Even though women work more than men; their wages are paid to the head of their house hold (Braybon, 1981). Inadequate distribution and lack of access to decent work not only affects women and men but is also effected by age, education, ethnicity and social status as well. In fact, agricultural workers get seasonal employment for about half a year and often they have to migrate for employment. During the off-season, they found daily wages job in construction, labourer and, helper. However, women could not move anywhere. Although a large majority $60 \%$ of rural women are engaged in agriculture and allied activities but receive only $20.8 \%$ of the total income, while the remaining $69 \%$ get $40 \%$ because they are rural men (Hanif, 2015).

In rural areas women usually work for 16 hours a day, which includes not only field work but also household chores, fetching of drinking water and fuel for cooking. These poor women further suffer from victimization, manipulation and exploitation just because they are totally illiterate and unorganized. Being very poor and needy, they do not have any 
other option but to accept work at very low wages and long hours. To make matters worse, these women also don't have equal access to quality education, adequate health facilities and well paid job opportunities.

\section{Objectives}

The agricultural sector is the only area of work where women have access to without any social barriers imposed on them. The purpose of this research is to identify the role of women in the field of agriculture in selected areas of Karachi. This role is equally important, if not more than that of men; therefore, they deserve recognition which unfortunately is not given to them.

In this research, the researcher is trying to identify the economic condition of these women working in the agricultural field. It has been observed that despite working hard in the field, these women remain deprived and sub-servant to men in financial matters. The study was also designed to analyse the economic contribution of agricultural working women in household income and also examine the pattern of expenses and savings of agricultural women labour in the rural areas of Karachi.

\section{Review of Literature}

Presence of women in economic activities is not only important for raising the family income and reducing poverty but also is an important contributor to the economic development of every country. The number of women participating in the labour force is not the only concern but also their wages on equal basis. Globally women are still getting less than $78 \%$ of the wages given to men for the same labour and in similar situation in both the developed and the developing countries. Mostly women participate economically in the informal sector and in many parts of the world provide $70 \%$ of the agriculture labour and produce $90 \%$ of the food (Claros, 2005).

Many researches provide evidence that women participation in various agricultural activities having a complementary role sharing activities related to crop production and livestock production and management. Rural women actively participate in farming and related activities like livestock caring management and food processing. (Franzel-1992, Sharma- 1997, Mamun-ur-Rashid, Muhammad \& Qijie- 2012, Arshad et al. 2013).

In fact, agricultural workers get seasonal employment for about half a year and often they have to migrate for employment. During the off-season, they found daily wages job in construction, labourer and, helper. However, women could not move anywhere. Although a large majority $60 \%$ of rural women are engaged in agriculture and allied activities but receive only $20.8 \%$ of the total income, while the remaining $69 \%$ get $40 \%$ because they are rural men (Hanif, 2015). 
According to research study in Uganda, agriculture is the main source of income for rural households. It is also crucial and main profession of women and a huge majority $90 \%$ of rural women out of $72 \%$ of the total employed in agricultural field while only $53 \%$ rural men contribute in farming. The study highlighted some facts that women tend to be involved at all stages with men becoming more active close to market time but men are responsible for cash crops, and if unfortunately crops becomes unprofitable men tend to loss interest in it, and women may take over its control and look after it. Men control earnings and all profits (FAO, 2000).

In India, women are active participant and important contributors in the agricultural sector. Most of the women are energetic participators in non-agricultural activities, which comprise household-industries and private sector. Women participation in agriculture is increasing with time and women are now acknowledged with the status of "agricultural worker" but still faced discrimination on wages and working status (Ghosh, 2014). In Pakistan a vast majority of women engaged with agriculture and allied activities. According to labour force survey 2015 of Pakistan $73 \%$ female and $33 \%$ male participated in agriculture/forestry and fishing sector which $42 \%$ of total labour force participation of both sexes (IFSP, 2015).

Pakistani women works at the same time as mother, nurse, household employment, social worker, despite this her economic contribution is unrecognized and unappreciated. Both genders equally contributed as individuals in productivity but one gender faced bias in economic and social level. He added that most development planning is based on physical input and outputs which ignored the perspective of human resources and the social dimensions of agriculture. Instead of this make plans for all humanity (Zafar, 2003).

The rural farm women make all these products for export level as well, but are not aware of what the market needs and their value, either national or international level. They need to increase their income through non-farm income generating activities. Women are involved in off-farm income generating activities while also maintaining responsibility for family nutrition, food security and child care and bear the burden of farming duties along with household task (Abbasi S., 2005).

Arshad pointed out these facts in 'The economic contribution of Pakistani women through their unpaid labour' 2008. She disclosed that women's countless involvement, as seen in household activities that includes preparing food, washing and ironing clothes, pick and drop of children for education, daily shopping for groceries, assisting children with their studies, caring for family members and besides all these activities, they also have to help in the economic well-being of their family (Arshad, 2008). Gul Hussan conducted a study in Karachi; he concluded that women actively participated in all farm activities along with their regular household responsibilities. They work without any 
wages even when they are owners of land or share croppers. It is a fact that women worked better as compared to men. Mostly women are involved in crop harvesting like chillies, tomatoes, cauliflower, peas and falsa. Women also worked in the fields like sowing, transplantation and harvesting while ploughing, irrigation, preparing of land were the male responsibilities (Hassan, 2008).

Doreen Stabinsky, provided evidence livestock in the agricultural production in the region is undertaken by small holders, on very small land holdings, by women, with a remarkable dependence on fisheries for protein in several countries, and dependence on livestock for draft power, manure, milk, and food security and income as well. Besides farming livestock is also a major source of income in the region. The sale of livestock and related products is an important source of income for Nepal, 44.4 percent in the mountain areas and 47.6 percent in the rural hills collect cash income from livestock. In Bhutan, about 10 percent of the country's population is dependent on yak based production and almost 86 percent farmers owned livestock. Farmers used animals for cultivation and transport and 68 percent household own different type of livestock, in Afghanistan (Stabinsky, 2014).

Similar as in our Pakistan around 49.1percent to overall agriculture value added and about 11.4 percent to national GDP accumulate by livestock. Farmers have improved their livelihood through livestock farming. It not only holds a potential as an income generating source but also is a viable solution to the poverty, malnutrition, hunger and a sustainable income generating activity. It is the prime income generating source to support and uplift for farmers by means of production (Junaid, 2015).

\section{Methodology}

The present study is an exploratory and basic descriptive research. For this research, the universe of population is the agricultural areas of Karachi. First of all, those rural areas of Karachi were identified, where agriculture or farming is done which includes: Malir, Gadap and Bin Qasim towns. In the period of local government these areas were distributed in towns but now the government has changed the local body system into districts and the chosen universe is now called as district Malir. In these areas fruits, vegetables, cotton and feed are grown and the farming of animals is done. Along with men a large number of women are also engaged in work in these fields.

The research in hand has been completed using the quantitative and qualitative research methods. Questionnaire is necessary for both quantitative and qualitative researches. The questionnaire composed of 80 questions which are based on both open ended and closed ended questions. In open-ended questionnaire, the respondents are able to respond as per their own will, whereas in close ended questionnaire, the respondents are subjected to 
restricted options. The questionnaire covers the various aspects of their lives and is designed to seek information regarding the following key areas of this research:

- Women agricultural labours personal profile like age, marital status, education number of children etc.

- Family profile of the working labour- nuclear or join, head of the family, family income, housing and living conditions.

- Work environment, wages and mode of wages, allied activities, working hour, holidays and extra allowances.

- Experiences of harassment at work place and within home verbal, physical and sexual violence.

For qualitative data of this research conducted in-depth interviews with some women. Case studies require a lot of time, detailed questioning during the time the women were busy working in the fields so it became even more tedious and difficult. That is why the researcher had to face a lot of difficulties in the completion of these case studies. Interviewing these working women during their fieldwork meant interruption in their work, which further resulted in loss of their wages. Interviewing them at home was also difficult as their domestic chores like looking after children, cooking and cleaning of their house, kept them busy and kept hindering the interviews. Five case studies are included in this research. Total 200 women, in agricultural areas of Karachi, who are connected to agriculture, were interviewed by using interviewing schedule. The researcher visited the agricultural areas of Karachi. Some interviews were conducted in homes, whereas, some in the fields or gardens of those areas. Once the data had been collected for the current study, the next step was its analysis. The conclusions are based on the results of data analysis. Statistical procedures were used in assembling, classifying, tabulating, and summarizing the numerical data.

\section{Results and Discussion}

Women constitute half of the population and their development reflects on the progress of a society. The status of women in a society is measured in terms of their level of income, employment, health, education as well as their role within family, community and society. Women are an energetic and productive work force in the Pakistan's economy. The weak economic condition of a family demands that their women to go to work and play a role for increasing the income of the family. In selected rural areas of Karachi women were found to be multi-functional; working in houses, doing daily house hold chores, looking after livestock along with other income generating work like embroidery, stitching and making rillies. The present study is based on the interviews conducted with 200 agricultural women labourer. 
Table: 1

Distribution of the respondents according to their age groups

\begin{tabular}{|l|c|c|}
\hline Age of respondents & Frequency & Percentage \\
\hline 15 to 20 & 14 & $7 \%$ \\
\hline 21 to 25 & 26 & $13 \%$ \\
\hline 26 to 30 & 27 & $13.5 \%$ \\
\hline 31 to 35 & 38 & $19 \%$ \\
\hline 36 to 40 & 32 & $16 \%$ \\
\hline 41 to 45 & 17 & $8.5 \%$ \\
\hline 46 to 50 & 27 & $13.5 \%$ \\
\hline Above 50 & 19 & $9.5 \%$ \\
\hline Total & $\mathbf{2 0 0}$ & $\mathbf{1 0 0 \%}$ \\
\hline
\end{tabular}

Above table is presenting the age of respondents. The eight age groups presented in the table number one the largest is of 31-35 years while 15-20 is the shortest, 133 respondents out of 200 fall in the range of 31 to above 50, it means 66.5 respondent over the age of 30 . In this age most of the women are married, have four or five children, work on the farm, have house chores and child care as well. These figures identifies that there is no specific age among agricultural women worker, as women of all ages work in the field.

Table: 2

Distribution of respondent according to their academic qualifications

\begin{tabular}{|l|c|c|}
\hline Academic Qualification & Frequency & Percentage \\
\hline Illiterate & 194 & $97 \%$ \\
\hline Primary & 5 & $2.5 \%$ \\
\hline Middle & 1 & $0.5 \%$ \\
\hline Total & $\mathbf{2 0 0}$ & $\mathbf{1 0 0 \%}$ \\
\hline
\end{tabular}

Education is an important factor and helpful source for human development. Education helps in making the right decisions and in the empowerment of women. A good saying is that when you educate a man you only educate a person, while if you educate a woman, you educate a whole family. When a woman is educated they play an important role within the family, community and national economy. Educated women transfers in their children good manners, values, strong moral attributes and develop a healthy environment. But unfortunately, we do not give priority to education, especially girl's education. Primary data shows that $97 \%$ of the women respondents are illiterate, while only $2.5 \%$ passed primary school and one passed middle school. Comparing this data with the literacy rate in Pakistan is very depressing, as the rural areas of a metropolitan city is the same as of any village. There are many reasons for this, such as lack of government schools, non-availability of male and female teachers and poverty. In most families, girl's education is not allowed, while in some families education is not considered necessary for both girls and boys. 
Table: 3

Distribution of the respondents according to their marital status

\begin{tabular}{|l|c|c|}
\hline Marital Status & Frequency & Percentage \\
\hline Unmarried & 42 & $21 \%$ \\
\hline Married & 128 & $64 \%$ \\
\hline Divorced & 20 & $10 \%$ \\
\hline Widowed & 10 & $5 \%$ \\
\hline Total & $\mathbf{2 0 0}$ & $\mathbf{1 0 0} \%$ \\
\hline
\end{tabular}

Marriage is a social contract which allows a man and women to live together and raise their family. The marriage is an important identification and recognition for both male and female of their new relationship with in the community. Marriage is a combination of social norms as well as religious obligation. It is also a very important ceremony in Pakistani society and married women are allowed greater freedom of mobility and work as compare to unmarried women. Child marriage is very common especially in rural areas. This happens even though the government has passed the child marriage restraint act and has advertised and campaigned for the awareness about this law. Table 03 shows that $64 \%$ of the women respondents were married, $21 \%$ unmarried, $10 \%$ divorced and $5 \%$ respondents widowed. The data also shows that a large number of women are working after marriage due to poverty as well as they want to share the financial burden of their husbands and families. Observation during this research shows that child marriage is not only common in the rural areas but also prevalent in the city as well. Most of these women got married at an early age of 14 to 15 years which means that the average marriage age in Pakistan has increased. This is the most fertile age of population growth. The changes in marriage patterns have a direct impact on fertility and population growth rate.

Table: 4

Distribution of respondents according to family structure

\begin{tabular}{|l|c|c|}
\hline Family structure & Frequency & Percentage \\
\hline Joint & 130 & $65 \%$ \\
\hline Single & 70 & $35 \%$ \\
\hline Total & $\mathbf{2 0 0}$ & $\mathbf{1 0 0 \%}$ \\
\hline
\end{tabular}

Joint family system is very common especially in rural or agricultural areas but due to modernization some want and like to have a nuclear family system. Table number 04 shows that $65 \%$ respondents live in a joint family system while $35 \%$ live as single families. Usually in urban areas trends are changing and most people preferred to live in a single family; but in rural areas the trend has not changed much. People living in a joint family system as it also support agricultural work. Living in a joint family system, women have more responsibilities and are beholden to their in-laws. Although women's situations more or less same in these areas but those women who live in a single family system, have influence over their husbands and can do something of their own choices. 
Table: 5

Distribution of respondents according to their family monthly income

\begin{tabular}{|l|c|c|}
\hline Family income & Frequency & Percentage \\
\hline $5000-7000$ & 74 & $37 \%$ \\
\hline $7001-9000$ & 106 & $53 \%$ \\
\hline $9001-11000$ & 14 & $7 \%$ \\
\hline Above -11000 & 6 & $3 \%$ \\
\hline Total & $\mathbf{2 0 0}$ & $\mathbf{1 0 0} \%$ \\
\hline
\end{tabular}

Table 5 shows that $53 \%$ respondents have a very low income of only seven to nine thousand rupees and in these days, it's very difficult to meet their basic needs with such a very low income, while only $3 \%$ have income above 11000 . Most people are living below the poverty line in Pakistan and these facts also highlighted in the millennium development goal of elimination poverty by 2013 by the government of Pakistan, which unfortunately has not been achieved.

Table: 6

Distribution of respondents according to their personal monthly income

\begin{tabular}{|l|c|c|}
\hline Personal monthly income & Frequency & Percentage \\
\hline $2000-3000$ & 102 & $51 \%$ \\
\hline $3001-4000$ & 82 & $41 \%$ \\
\hline $4001-5000$ & 14 & $7 \%$ \\
\hline Above -5000 & 2 & $1 \%$ \\
\hline Total & $\mathbf{2 0 0}$ & $\mathbf{1 0 0 \%}$ \\
\hline
\end{tabular}

Women belong to the poorest income group in our society and even though they work hard, their income is very low. Facts show a very clear picture of women's financial status. $51 \%$ respondents earn about three thousand monthly, $41 \%$ earn four to five thousand monthly, while only 7\% respondents earn five thousand monthly. In 2011 the government of Pakistan fixed the minimum monthly salary at twelfth thousand for labourers but unfortunately this is not been implemented and the government is not doing anything about it.

Table: 7

Distribution of respondents according to when they started agriculture work

\begin{tabular}{|l|c|c|}
\hline Started agriculture work & Frequency & Percentage \\
\hline From childhood & 166 & $83 \%$ \\
\hline During studies & 2 & $1 \%$ \\
\hline After marriage & 32 & $16 \%$ \\
\hline Total & $\mathbf{2 0 0}$ & $\mathbf{1 0 0 \%}$ \\
\hline
\end{tabular}


Table 7 shows that $83 \%$ respondents started working since childhood, $16 \%$ started working after marriage. This table indicates the prevalence of child labour is common in our society and a large number of respondents started working from their childhood. Due to engagement in paid work at an early age they could not go to school for an education. Their work helped in contributing to the family income.

Table: 8

Distribution of respondents whether they worked whole year on the farm

\begin{tabular}{|l|c|c|}
\hline Work in the field & Frequency & Percentage \\
\hline Yes & 152 & $76 \%$ \\
\hline No & 48 & $24 \%$ \\
\hline Total & $\mathbf{2 0 0}$ & $\mathbf{1 0 0 \%}$ \\
\hline
\end{tabular}

Table shows that most respondents, $76 \%$ work the year round on the farm while $24 \%$ do not work whole year. In off season, they do some other work like embroidery, croshiya, rilly making, and any other work that is available, but sometimes when they do not get any work or job, they faced critical situation and it is very difficult for them to fulfill their daily needs.

Table: 9

Distribution of respondents according to do the other work along with agriculture

\begin{tabular}{|l|c|c|}
\hline Work along with agriculture & Frequency & Percentage \\
\hline Yes & 116 & $58 \%$ \\
\hline No & 84 & $42 \%$ \\
\hline Total & $\mathbf{2 0 0}$ & $\mathbf{1 0 0 \%}$ \\
\hline If yes than types of work & 7 & \\
\hline Stitching & 65 & $6 \%$ \\
\hline Embroidery, Croshiya \& rilly & 26 & $56 \%$ \\
\hline Animal husbandry & 18 & $22.4 \%$ \\
\hline Others (broom making) & $\mathbf{1 1 6}$ & $15.5 \%$ \\
\hline Total & & $\mathbf{1 0 0 \%}$ \\
\hline If not then why & 30 & $35.7 \%$ \\
\hline Manage within income & 20 & $23.8 \%$ \\
\hline No permission for other work & 34 & $40.5 \%$ \\
\hline Doesn't have any other skill & $\mathbf{8 4}$ & $\mathbf{1 0 0 \%}$ \\
\hline Total & & \\
\hline
\end{tabular}

As per data $58 \%$ respondents do other works along with agricultural work while $42 \%$ does not any other work along agricultural work. Data shows that $56 \%$ respondent do embroidery, making Rilly and croshiya along with agricultural work, $22.4 \%$ do animal 
husbandry, $15.5 \%$ are involve indifferent works such as embroidery, croshiya, rilly, aalo chaat, chana chaat, aalo chawall and sharbat. Data shows that $40.5 \%$ respondent do not do other work because they do not have any other skills, 35.7\% respondent manage within their income while $23.8 \%$ do not have permission for other work. Women's participation in agriculture is common and acceptable but in other sectors many families do not allow it. In rural or sub-rural areas women's mobility is very limited; they do not have easy access to markets and cannot sell their products themselves. Their male family members run the marketing system and they cannot inform the women about new designs or market requirement. These skilled women do not get the right price although their work is very precious and valuable. There are few women who in charge of the whole process.

Table: 10

Distribution of respondents according to whether do they sell home based food item

\begin{tabular}{|l|c|c|}
\hline Sell home based food item & Frequency & Percentage \\
\hline Yes & 54 & $27 \%$ \\
\hline No & 146 & $73 \%$ \\
\hline Total & $\mathbf{2 0 0}$ & $\mathbf{1 0 0 \%}$ \\
\hline Types of Home based items & & \\
\hline Pickle \& chattni & 22 & $41 . \%$ \\
\hline Dry and sell vegetables & 11 & $20.4 \%$ \\
\hline Making jam & 7 & $13.0 \%$ \\
\hline Chana chat & 10 & $18.5 \%$ \\
\hline Aalo chat & 4 & $7.4 \%$ \\
\hline Total & $\mathbf{5 4}$ & $\mathbf{1 0 0 \%}$ \\
\hline
\end{tabular}

According to $73 \%$ respondents they do not sell home based item while $27 \%$ respondents make and sell home based items and increase their income. Data shows that $41 \%$ respondents make pickle and chattni with mangoes at home for sale, $20.4 \%$ sell dry vegetable, and $18.5 \%$ make and sell chana chat. Along with their agriculture work, these women make these home-based items and their children sell outside and sometimes they sell at home themselves. Some women make these items on special occasion or holidays like Friday, Sunday, 14 August, Eid-ul-Fitr and Ramzan. These food items are very popular and profitable business in Karachi but these respondents live in poor localities and most of these people in their surrounding are from the same socio-economic group, that's why they do not earn much income from their products. 
Table: 11

Distribution of respondents according to how they choose to spend their earnings

\begin{tabular}{|l|c|c|}
\hline Spend money as their own choice & Frequency & Percentage \\
\hline Yes & 134 & $67 \%$ \\
\hline No & 66 & $33 \%$ \\
\hline Total & $\mathbf{2 0 0}$ & $\mathbf{1 0 0 \%}$ \\
\hline If yes then how & & \\
\hline Food / household expensive & 67 & $50 \%$ \\
\hline Clothes or makeup & 8 & $6 \%$ \\
\hline On their children & 48 & $35.8 \%$ \\
\hline On their relatives & 11 & $8.2 \%$ \\
\hline Total & $\mathbf{1 3 4}$ & $\mathbf{1 0 0 \%}$ \\
\hline If not then why & & \\
\hline Submitted to head of the house & 66 & $100 \%$ \\
\hline Total & $\mathbf{6 6}$ & $\mathbf{1 0 0 \%}$ \\
\hline
\end{tabular}

When asked about spending income that $33 \%$ respondents do not spend their income to their own choice while $67 \%$ spend their income on their own choice. Poverty is very common in the farm women and men as well. They do not have any choice except to fulfill their basic needs. So both genders are responsible for all household expenses. Data shows that in our society if women are working, they do not spend their income on themselves but prefer to spend it on their children or on their home. $50 \%$ respondents spend their income for food and household expensive, $35.5 \%$ spend it on their children, and $8.2 \%$ spend it on relatives, while only $5.9 \%$ spend on their own needs like clothing.

Table: 12

Distribution of respondents according to access to wages of farm work

\begin{tabular}{|l|c|c|}
\hline Access to wages of farm work & Frequency & Percentage \\
\hline Yes & 135 & $67.5 \%$ \\
\hline No & 65 & $32.5 \%$ \\
\hline Total & $\mathbf{2 0 0}$ & $\mathbf{1 0 0 \%}$ \\
\hline If not then why & & \\
\hline Family receive wages & 16 & $24.6 \%$ \\
\hline Husband receive wages & 49 & $75.4 \%$ \\
\hline Total & $\mathbf{6 5}$ & $\mathbf{1 0 0 \%}$ \\
\hline
\end{tabular}

According to $67.5 \%$ respondents receive wages for their work, while $32.5 \%$ do not receive separate wages for their work, as their wages are included in whole family wages. The figure indicates that women do not have access and control on their wages $75.4 \%$ respondent's wages were received by their husbands and $24.6 \%$ by their families. This 
reflects as a picture of women's subordination or oppression. Women are not getting their work income although the work hard it. Researcher observed that in some areas where the whole family works together male, female and children, the women and children do not receive their wages; but the total amount is received by the head of the family, usually a male person.

Table: 13

Distribution of respondents according to working hours

\begin{tabular}{|l|c|c|}
\hline Daily working hours & Frequency & Percentage \\
\hline 8 hours & 30 & $15 \%$ \\
\hline 9 hours & 125 & $62.5 \%$ \\
\hline More than 9 hours & 45 & $22.5 \%$ \\
\hline Total & $\mathbf{2 0 0}$ & $\mathbf{1 0 0 \%}$ \\
\hline
\end{tabular}

A large number of respondents, $62.5 \%$ for 9 hours, and $22.5 \%$ work for more than 9 hours while only $15 \%$ respondents work for 8 hours. Farm workers leave home at 6 am or $6.30 \mathrm{am}$, they have to reach the farm by 7 am as the distance from house to farm is a 30 or 40 minutes' walk. They go to work by foot and no transport is used for this purpose. They work on the farm from 7 am to $01 \mathrm{pm}$ with a break of one hour for lunch for which they go back home.

Table: 14

Distribution of respondents according to do they earn equal wages as men

\begin{tabular}{|l|c|c|}
\hline Earn equal wages as men & Frequency & Percentage \\
\hline No & 200 & $100 \%$ \\
\hline Total & $\mathbf{2 0}$ & $\mathbf{1 0 0 \%}$ \\
\hline If not then why & & \\
\hline Male do more work & 90 & $45 \%$ \\
\hline Male work is difficult & 110 & $55 \%$ \\
\hline Total & $\mathbf{2 0 0}$ & $\mathbf{1 0 0 \%}$ \\
\hline
\end{tabular}

According to table 14 quantitative data gives a very clear picture of discrimination against women. In the first wave of women liberation movement, the feminist struggled for equal wages, now after a century the situation has not changed; women are still working for lower wages than men. All 100\% respondent are not getting equal wages as men. This shows the control and domination on women's perception because even though she does the same type of work as men, she is treated unequally and receives lower wages than men. Women do not protest against this discrimination as they think that males do more and harder work as compared to them. 


\section{Conclusions}

This research paper explored the role of women agricultural laborers in development of agriculture of Karachi. Facts have proved that women participation is very essential for the development of country. Women of Karachi continuously play an important role in the development of the city and country as well. This study also highlighted the participation of women in agricultural activities along household responsibilities. They play a vital role in agricultural activities such as preparation of land, crop production, managing and caring livestock and poultry. These women work in the field with male and actively participate in cotton picking, harvest and picking of vegetables and fruit. They also take care of animals such as feeding, milking, bathing and nursing. Almost women work eight or nine hours outside of home but they earn only three to five thousand monthly, gender wage gap affect women financial condition. The research paper also focused the obstacles which are the barrier to women agricultural labourers economically strong such as unpaid and care work in family they do not have much time to involve in paid work. They mostly work done without any wages. They could not involve in incomegenerating activities regularly. Women agricultural labourer exploited economically because they work hard both sides farm and home but receive earning very low. As per finding of this research in agricultural areas, women face barriers in land ownership, access to technological training, education and decision-making powers. It is a known fact that lack of education and technical skills has limited the employment opportunities for rural women and resulting in their increased level of poverty. Through education and development of technological skills would ensure an increase in employment opportunities and improve their status within the family and society.

\section{Recommendations}

The government, well-aware of the economic importance of the agricultural sector devises and implements policies for its productivity but these reforms did not come up with any significant results; as their policies are not backed by gender segregated data and have no provisions to facilitate the female productivity in agriculture

1. Strengthen women farmer by providing them skill development trainings.

2. Highlighted the women participation in agriculture business and create new opportunities for them.

3. Introduce new technical courses in training institutes for women related to agriculture and market requirements such as usage of machinery, driving and computer skills.

4. Development of an irrigation system is needed to increase, both agricultural production and employment opportunities for women in agriculture and allied activities. 
5. Establish a minimum daily wage act for women farmers and ensure its implementation.

6. Introduced marketing techniques and strategy to these women to develop their own business and increase their income.

\section{References}

Abbasi, S. 2005. Women Labour-Unrealized Potential. Dawn, June 27, 2005.

Arshad et al. (2013). Women's Participation in Livestock Farming Activities, The Journal of Animal \& Plant Sciences, vol. 23:1, pp. 304-308.

Arshad, Zehra. (2008) The Economic Contribution of Pakistani Women through their Unpaid Labour, Islamabad, Pakistan, Society for Alternative Media and Research and Health Bridge, Pakistan, pp.1-25.

Bank, A. D. (2015). Women in the Workforce: An Unmet Potential in Asia and Pacific. Manila: Asian Development Bank, pp.2-3.

Braybon, G. (1981). Women Workers in the First World War: The British Experience. London: Croome Helm, p.15.

Brownlee, W. E., \& Brownlee, M. M. (1976). Women in the American Economy: A Documentary History, 1675 to 1929. New Haven: Yale University Press, p.91.

Claros, A., Zahidi, S. \& World Economic Forum. (2005). Women's Empowerment: Measuring the Global Gender Gap. Boston, Mass.: Harvard Business Review.

FAO (2016). Climate Change, Agriculture and Food Security, FAO.

FAO. (2015). Women in agriculture of Pakistan, Islamabad, Pakistan, Food and Agriculture Organization, pp.17-18

FAO. 2000. IFAD's Gender Strengthening Programme for East and Southern Africa Uganda Field Diagnostic Study.

Franzel, S. C., Van, H. H., YaEr meremer instityut., \& C.A.B. International. (1992). Research with farmers: Lessons from Ethiopia. Wallingford: C.A.B. International for Institute of Agricultural Research, Ethiopia. 
Ghosh, Mun. M. \& Dr. Ghosh. Arindam. (2014). Analysis of Women Participation in Indian Agriculture, International Journal of Gender and Women's Studies, vol.2:2, pp.271-281.

Hanif, Dilmurad. (2015). https://baluchsarmachar.wordpress.com/2015/09/23/lif ting-ofsand-gravel-from-malir-river-affects-districts-waterbed-agriculture/ (Retrieved on 5.2.17)

Hassan, Gul kalmati. (2008). The Impact of Urban Construction on Women's Livelihood: A case Study of Malir Karachi, Pakistan, Shirkatgah, p.19.

Junaid Alvi.et. al. (2015). Impact of Livestock in Uplifting Rural Livelihood, Pakistan Journal of Agriculture \&. Research, vol.28:3, pp.287-293.

Labour Force Survey (2014-15), Pakistan Bureau of Statistics, Islamabad, Government of Pakistan.

Labour Force Survey (2014-15). Pakistan Bureau of Statistics, Islamabad, Government of Pakistan.

Lu, J. L. (2011). Relations of Feminization of Agriculture and Women's Occupational Health- The Case of Women Farmers in the Philippines. Journal of International Women's Studies, vol.12:4, pp.108-118.

Mamun-ur-Rashid, Muhammad, \& Qijie, Gao. (December 01, 2012). Rural Women in Livestock and Fisheries Production Activities: An Empirical Study on Some Selected Coastal Villages in Bangladesh. Asian Journal of Agriculture and Rural Development, vol.2:4, pp.658-667.

Mirza. Shazia. (2014). Pakistan Gender News: Women's Employment, Web Desk in Economic Empowerment, Featured August18, 2014, http://www.pakistangendernews.org/womensemployment/ (Retrieved 10.09.2016).

Nergus, Y., Ahmed, S. I., \& Sharif, M. (January 01, 2005). Impact of Contaminated Vegetables, Fruits and Fodders on Human Health by Malir River Farms Karachi. Journal of the Chemical Society of Pakistan, vol.27:6, pp.561-571.

Rocca, Valeria, Bossányi, Zsófia \& Giuseppe, Stefania Di (2014). Rural Women in Eastern Europe and Central Asia, FAO. p.36 
Sharma, S.D., S. Tripathy and P. Gurung, (1997). Gender Dimensions in Biodiversity Management: India. Report submitted to FAO Regional Office for Asia and the Pacific, Bangkok, Thailand.

Stabinsky, Doreen (2014). Defining Role of Agriculture in South Asia, Climate Action Network South Asia, Bangladesh, pp.2-5.

United Nations Development Programme, (2016). Human Development Report 2015: Work for Human Development.

Wasnik, K. P. (2006). Women in Agriculture: Strategy for Socio-Economic Empowerment. New Delhi: Gyan Books, p.02.

Zafar, I. (2003). Daily Dawn: Female Labour Force in Agriculture. Dawn-The Internet Ed. Retrieved July 08, 2016, from http: www.Dawn.Com.

Ms. Rukhsana is Teaching Assistant in the Centre of Excellence for Women's Studies, University of Karachi.

Dr. Nasreen Aslam Shah is Meritorious Professor: Chairperson in the Department of Social Work and Director, Centre of Excellence for Women's Studies, University of Karachi. 